\title{
ResearchArticle
}

\section{Evaluation of recurrent selection derived lines in safflower (Carthamus tinctorius L.)}

\author{
N.G. GAWANDE, A.E. PATIL, P.C. AWACHAR AND P.B. GHORPADE
}

\begin{abstract}
SUMMARY
The present study was undertaken; to evaluate the response of recurrent selection derived lines by the testing of $\left(\mathrm{C}_{3}\right)$ derived lines for genetic variability, genetic advance and heritability and to assess the effect of selection on other quantitative traits. The 16 half-sib families were selected from $3^{\text {rd }}$ cycle of recurrent selection were grown for evaluation in Randomized Block Design in Rabi 2009 -10 along with check varieties Bhima and $\mathrm{A}_{1}$. The expected genetic advance expressed as per cent of population mean at 10 per cent was high for seed yield per plot (48.84) followed by seed yield per plant (28.88). The expected genetic advance per cent over Bhima at 10 per cent selection intensity was high for seed yield per plot (28.27) followed by seed yield per plant (22.78). In safflower seed yield per plant was positively and significantly correlated with days to maturity, number of capitula per plant, number of seeds per capitulum and 100 seed weight. Days to maturity and seed yield per plant had exhibited significant and positive correlation. Two halfsib families were identified for testing in preliminary yield evaluation trial.
\end{abstract}

Key Words : Safflower, Random mating population, Evaluation

How to cite this article : Gawande, N.G., Patil, A.E., Awachar, P.C. and Ghorpade, P.B. (2015). Evaluation of recurrent selection derived lines in safflower (Carthamus tinctorius L.). Internat. J. Plant Sci., 10 (1): 14-18.

Article chronicle : Received : 10.01.2014; Revised : 05.11.2014; Accepted : 19.11.2014

\section{MEMBERS OF THE RESEARCH FORUM}

Author to be contacted :

N.G. GAWANDE, Department of Agricultural Botany, College of Agriculture, NAGPUR (M.S.) INDIA

Email: nitingawande570@gmail.com

Address of the Co-authors:

A.E. PATIL AND P.C. AWACHAR, Department of Agricultural Botany, College of Agriculture, NAGPUR (M.S.) INDIA

Email: awachar.prashant@yahoo.com, amolpatil88@gmail.com

- - - - - - - - - - - - - - - - -

P.B. GHORPADE, AICRP on Linseed, Safflower and Mustard, College of Agriculture, NAGPUR (M.S.) INDIA

Email: pbghorpade@rediffmail.com 